\title{
SUCEDÂNEOS À ÉTICA CLÁSSICA: REFLEXÕES SOBRE O AGIR HUMANO E O ALÉM DO HOMEM NIETZSCHEANO
}

\author{
Mariana Paolozzi Sérvulo da CUNHA ${ }^{1}$
}

- RESUMO: Baseado nas reflexões de Nietzsche sobre a ação humana e o além-do-homem, este artigo discute sua crítica demolidora à ética clássica à luz do contexto mais amplo do século XIX de desconstrução dos valores éticos enraizados até então. Duas questões são enfatizadas: A suspeita lançada por Nietzsche sobre a ética clássica desencadeou um vazio ético? A efetivação histórico-social da Unwertung seria apenas uma utopia?

- PALAVRAS-CHAVE: Nietzsche; ética; desconstrução, razão; dualismo.

\section{Apresentação}

Discutir-se-á aqui o pensamento nietzscheano (à luz do processo de desconstrução da ética clássica iniciado no séc. XIX) procurando-se delinear o projeto desse autor e o que sobrevém após sua crítica devastadora à ética. A questão da derrocada da ética clássica vincula-se à problemática do ceticismo e do relativismo, vistos como elementos provocadores da desconstrução do ciclo dos grandes sistemas éticos do Ocidente.

Ao ser abalado o status de preeminência de uma razão incontestada, universal e absoluta, presente nas éticas de até então (de Sócrates e Platão, passando por Santo Agostinho e Santo Tomás, a Hegel), o fim

\footnotetext{
1 Doutora em Filosofia pela UNICAMP
} 
dos grandes sistemas que propunham uma ética de abrangência universal tornou-se a principal característica do complexo panorama da ética atual.

Com a negação do Absoluto, brotaram racionalidades separadas de uma razão superior unificadora: difundiu-se o relativismo, e nesse contexto se desenvolvem tanto o pluralismo ético quanto o ceticismo com relação à possibilidade da existência de uma ética de caráter universalizante.

Embora algumas teorias busquem estabelecer a ética e o direito e, em suma, qualquer disciplina normativa - sem qualquer vínculo com a realidade, nota-se a estrita dependência entre as teorias éticas e o desenvolvimento histórico da teoria do conhecimento. A ética de Kant, como sabemos - e a rigor toda a sua filosofia - consistiu num esforço para superar a impotência da razão, tal como se via demonstrada pelos céticos britânicos, especialmente Hume. Kant efetuou uma verdadeira revolução copernicana também no que diz respeito à ética, ao pretender, ao contrário dos pensadores do passado, dar-lhe um fundamento formal. Depois dele, porém, tanto a reflexão estritamente filosófica (v.g. Nietzsche) quanto o pensamento científico (v.g. Darwin, Freud, Marx), exibiram novas facetas do ceticismo sob a forma do que se convencionou chamar "filosofias da suspeita".

A partir desse contexto e devido à influência do desmantelamento da ética clássica no estilo de vida e nas mentalidades contemporâneas, interessa-nos discutir a concepção nietzscheana a respeito do agir humano e do além do homem visto ser ele um dos precursores desse movimento de ruptura.

Ao falarmos sobre a contestação da ética clássica e sobre a transvaloração (Umwertung) nietzscheana, é preciso, antes de mais nada, ter em mente que esse autor escreveu assistematicamente sob a forma de aforismos, e originariamente não tencionava estabelecer nenhum "sistema" ético ou algo do gênero. Refletiremos, por isso, sobre o significado da Umwertung e sobre o modo de sua manifestação. Sua efetivação histórico-social seria apenas uma utopia? A "desconstrução" dos valores éticos consagrados ou a suspeição sobre eles lançada por Nietzsche desencadeou um vazio ético?

A Unwertung passa pela supressão das oposições de usuais conceitos tais como coisa em si/aparência; corpo/espírito; razão/irrazão. Das dicotomias provém uma limitante maneira de pensar, e é precisamente 
nelas que reside a base da religião e da metafísica: ao contrário do que propagam a religião cristã e a metafísica, a consciência e o corpo (ou matéria/espírito; corpo/razão), por exemplo, não se opõem, mas acham-se estreitamente vinculadas. Poderíamos também pensar que Nietzsche deseja suprimir as dicotomias em favor de uma unidade geradora de uma síntese -, mas não se trata disso, a supressão das dicotomias se daria em favor da coexistência de uma multiplicidade (e não dualidade) que não fosse polarizadora.

Ele rejeita a oposição entre sentidos, impulsos, instintos, de um lado, e espírito, consciência e razão de outro ("..a consciência nunca se opõe ao instinto de maneira decisiva"; Para além de Bem e Mal, 3).

A crítica à noção de razão que divide o mundo em sensível e inteligível é expressão da crítica nietzscheana ao dualismo. Em Nietzsche não se encontra a tensão entre o racional e o irracional, visto que a razão (e também a vontade) decorre de uma mesma noção ficcional: a noção de alma como algo distinto do corpo.

Se a humanidade agisse somente por meio dessa razão (à qual se atribui a pretensa função de governo e orientação dos atos humanos), teria perecido. Por sorte a humanidade é também uma espécie animal que obedece aos instintos. A própria razão está a serviço dos instintos, e apenas tardiamente ela predominou entre os gregos (Gaia Ciência, 310) se expandindo à posteridade.

Falar em faculdades do espírito, razão e vontade, implica supor a existência de algo distinto do corpo, com natureza e atividades específicas. Nietzsche opõe-se a essa idéia de forma bombástica: "efetivamente o 'espírito' ainda se assemelha ao máximo a um estômago" (Para além de Bem e Mal, 230). As principais atividades que se atribuem às funções do espírito se resumem a processos de assimilação, discriminação e secreção. E o que é isso tudo senão manifestação de processos orgânicos?

Enfatizemos a ruptura que Nietzsche quer introduzir na antiga ligação do pensamento com a razão e a consciência (que de longa data é considerada como natural). Há em nosso organismo uma infinidade de pensamentos - o pensamento está espalhado pelo corpo inteiro - diferentes do pensamento racional, que não atingem a consciência. Não atingimos outra "realidade" que a de nossos instintos: também nosso pensar é somente uma relação desses instintos. E o conhecimento, isto é, o interpretar, também está ligado aos instintos.

Dentro dessa concepção de ser humano não há mais lugar para a reflexão 'racional' e estritamente subjetiva. Importa frisar a impessoalidade do ato de pensar. Em Para além de Bem e Mal (17), Nietzsche escreveu: "Es denkt" (no neutro e impessoal) e não na primeira pessoa do 
singular ("Ich denke"). Sobre a origem, o significado e a motivação dos pensamentos, ele diz:

O pensamento emerge em mim - de onde? Por meio de que? Não o sei. Ele vem, independentemente de minha vontade, costumeiramente envolto e ensombrecido por uma multidão de sentimentos, desejos, aversões, também de outros pensamentos...Nós o extraímos de tal multidão, o limpamos, colocamolo sobre seus pés. .quem faz isso tudo - não o sei, e sou aqui seguramente mais espectador do que causa desse processo. . .Que em todo pensar parece tomar parte uma multiplicidade de pessoas - : isso não é, de maneira alguma, fácil de observar, somos fundamentalmente mais fortes no inverso, ou seja: ao pensar, não pensar no pensar.

A origem do pensamento permanece oculta; é grande a probabilidade de que ele seja apenas o sintoma de um estado muito mais abrangente.... (Fragmento póstumo; GA XIV, 40 s., Junho-Julho de 1885, n.38 [1]; KGW VII 3, p. 323 s.)

O ser humano é uma tão complexa organização de vontade de potência, que não pode mais experimentar aquilo que, no 'fundo', o impele. Todavia, com o abandono da razão e da consciência, Nietzsche estaria inevitavelmente advogando um retorno à animalidade, sinômino de brutalidade e barbárie?

Ele fala de um ser humano pensante liberto da coação da razão e da consciência:

Pois, eu o repito, o homem, como toda criatura viva, pensa continuamente, mas não sabe disso; o pensamento que se torna consciente é apenas a mínima parte dele, digamos a parte mais superficial, a parte pior ... (Gaia Ciência, 354)

Ao falarmos sobre os instintos, no seu predomínio sobre a razão, é inevitável que nos venham à mente imagens do homem paleolítico ou algo semelhante. Mas não se trata disso, de uma volta a um estado primitivo, desprovido de linguagem. Nietzsche busca uma posição distinta, representada pelo seu além-do-homem.

E isso é exeqüível?

Por todos os lados para os quais distendamos o pensamento nietzscheano deparamos com aporias. Nietzsche pretende nos remeter, não ao impensável, mas ao campo do diverso, não à ausência de linguagem, mas à alteridade. No entanto, os ecos de seu pensamento que nos atingem são os dos paradoxos, dos limites da linguagem e do pensamento. Em outras palavras, com o seu pensar Nietzsche nos apresenta aporias que se voltam contra ele mesmo e parecem revogar sua filosofia: pois é como se ele quissesse raciocinar o não-raciocinável (como se quisesse raciocinar o não-raciocinar). 
Ora, podemos dizer que ao orbitar no insólito campo não dualista do irracional e racional, Nietzsche viabiliza a possibilidade dos "pensamentos que não pensam o pensar". Mas a essa tese parece acoplar outra, implausível, a de querer pensar o não-pensar, ${ }^{2}$ e assim nos confrontamos com uma grande dificuldade de sua filosofia.

Ressalte-se que a Nietzsche interessa a transvaloração do niilismo pela vontade de potência. Sua concepção geral da vida e da cultura é dominada pela idéia da vontade de potência como força criadora de valores afirmativos. Não se trata mais de uma vontade subjetiva, antropomórfica, a vontade de potência implica o aniquilamento e a reinvenção das categorias clássicas do pensamento, como por exemplo as de alma e de vontade.

A vontade de potência reina no mundo inorgânico, que por sua vez não se distingue do orgânico (reiterando, não há diferença entre os mundos inorgânico e orgânico; entenda-se mundo inorgânico/orgânico como o mundo da manifestação de forças, manifestação da vontade de potência).

A explicação de nossa vida instintiva "como o desenvolvimento interno e ramificado de uma forma fundamental e única da vontade - isto é, da vontade de potência" (Genealogia da Moral, III, 28), não implica irracionalismo.

Nenhuma vontade de potência é uma "vontade cega". Nietzsche admite um "conhecer", um perceber também para o mundo inorgânico/orgânico. O pensamento está disseminado pelos corpos, pelo domínio do inorgânico/orgânico (trata-se de um pensar que não passa pelo pensar sobre o pensar). E eis um ponto importante: a inteligibilidade do mundo está, não mais na razão (quer seja ela uma razão transcendente, ou imanente), mas na vontade de potência, é ela que dá sentido à realidade:

O mundo visto de dentro, o mundo determinado e designado por seu"caráter inteligível" - seria justamente "vontade de potência" e nada além disso. ${ }^{3}$ (Para Além de Bem e Mal, 36)

A "vontade de potência" continuamente interpreta (interpretar é um meio de se apropriar daquilo que é interpretado). Não havendo fatos, nada em-si, nem objetividade, há somente interpretações.

2 Pensar sobre o não-pensar é uma coisa (e isto consideramos plausível), mas pensar o não-pensar é algo diferente e impraticável.

3 Os pensadores, Para Além de Bem e Mal, aforismo 36, p.275. 
Mas como o positivismo, o materialismo, o realismo e o idealismo (teoria às quais Nietzsche se opõe), também a teoria da vontade de potência seria apenas interpretação. Não se colocariam, então, sempre, interpretações contra interpretações? Não se poderia dizer que a toda interpretação caberia pleitear a mesma ambição de verdade?

Quem, como Nietzsche - que afirma não haver fatos, mas somente interpretações (todo acontecer está imbuído de um caráter interpretativo $)^{4}$ - deve esperar a inevitável pergunta: o que é a interpretação?

Conforme Nietzsche, seria um equívoco colocar um intérprete por detrás da interpretação (pois tal sujeito não existe) e também o interpretar "não tem existência como um ser", no sentido de permanência e imutabilidade, mas se manifesta como "um processo, um vir-a-ser". ${ }^{5}$

O que se deve reter é que a interpretação não comporta interpretação (pois todo interpretar tem um caráter perspectivo, relativo). Ora, Nietzsche pretende interpretar adequadamente o interpretar. ${ }^{6} \mathrm{O}$ que está por detrás dessas questões é a discussão sobre "a verdade" da vontade de potência e os julgamentos de valores.

A perspectividade de toda interpretação torna-se um problema (que se volta contra o próprio pensamento nietzscheano): o da legitimidade da filosofia de Nietzsche. Pois se há inumeráveis interpretações do mundo não há nenhuma correta ou superior.

Não havendo conhecimento absoluto, o caráter perspectivo pertence à existência. Assim, toda explicação do mundo seria uma interpretação perspectiva: por exemplo, a interpretação positivista, como também a da vontade de potência.

Segundo Nietzsche, se todo interpretar tem caráter perspectivo, relativo, é porque somos seres perspectivamente interpretantes: se todos os outros seres também interpretam, não temos como investigar. Podemos ver somente sob nossa perspectiva; mesmo quando queremos pôr em perspectiva nosso perspectivar, permanecemos sob nossa perspectiva. ${ }^{7}$ O ser humano torna-se prisioneiro de si mesmo, e a possibilidade de sua liberação estaria no além-do-homem.

O mundo concebido como o caos de relações de forças que se unem e se separam, concebido como vontade de potência, seria também uma

4 GA XIII, 64; outono de 1885 - primavera 1886, n.1 [115]; KGW VIII 1, 34: "O caráter interpretativo de todo acontecer. Não há qualquer acontecimento em si...."

5 Fragmento póstumo de VP. 556; GA XVI, 61. Outono de 1885-outono 1886, n. 2 [151]; KGW VIII 1, 138.

6 Cf. Müller-Lauter, op.cit., pp. 120-125.

7 Cf. Muller-Lauter, op. cit., p.137. 
interpretação perspectiva ao lado de inúmeras outras. Diante da relatividade de todo explicar-o-mundo, o que poderia ser dito em favor da pretensa superioridade da interpretação nietzscheana?

A doutrina da vontade de potência, se por um lado conduz à compreensão da perspectividade de todas as interpretações, por outro pretende declarar a verdade sobre a efetividade. Há, então, um critério de verdade surgido dessa doutrina, e Nietzsche nos teria fornecido esse critério para discernir o que entende por verdade. Ele estaria baseado na intensificação da vontade de potência, e com base nesse critério estaria colocada a "infinita interpretabilidade do mundo".

Toda interpretação é um sintoma de crescimento ou declínio. Se uma explicação serve à intensificação da vontade de potência, então ela é mais verdadeira do que aquelas que simplesmente conservam a vida, tornando-a apenas suportável.

Mas o importante é não apenas "interpretar" o mundo, e sim transformá-lo. Na verdade, todo transformar é interpretar e todo interpretar é transformar. No entanto, a principal transformação ainda estaria por vir. É aqui que entra a questão do além-do-homem.

Antes de abordarmos a questão do além-do-homem e do agir humano, vejamos algumas características do ser humano nietzscheano. Quem é ele?

Não é um individuum (pois não há átomos nem essências), mas a totalidade do orgânico/inorgânico. A perspectiva dualista (que divide o ser humano em corpo e alma) nos leva também a uma avaliação equivocada sobre a vida e a morte:

Falsidade fundamental das avaliações do mundo sensitivo face ao mundo morto.... Não nos deixemos pensar o retorno ao desprovido de sensibilidade como um retrocesso! Nós nos tornamos inteiramente verdadeiros, nós nos completamos. A morte há que ser reinterpretada! Nós nos reconciliamos assim com o efetivo, isso é, com o mundo morto. (Fragmento póstumo da primavera-outono de 1881, 11 (70), KGW V 2, 336)

E em Gaia Ciência (109) também lemos: "Guardemo-nos de dizer que a morte é oposta à vida. O vivente é somente uma espécie de morto, e uma espécie muito rara".

Nietzsche quer reinterpretar o ser humano: na medida em que o orgânico é uma síntese de forças inorgânicas, nele vive também o inorgânico.

O ser humano abrigaria em si, "não"uma alma imortal", mas muitas almas mortais" (Humano Demasiado Humano; 17). E "Nosso corpo nada 
mais é do que um edifício coletivo de várias almas" (Para Além de Bem e Mal, 19).

Quando utiliza o termo "alma", Nietzsche lhe atribui não o sentido cristão e metafísico, de substância incorpórea distinta do corpo, mas o emprega no sentido de "seres microscópicos que formam o corpo". ${ }^{8}$ Ressalte-se que a vontade de potência se exerce nesses numerosos seres vivos microscópicos que constituem o organismo.

Nietzsche rompe com a noção grega do ser humano como animal racional, com a noção cristã do ser humano como imagem de Deus. Enfim, nele se dá a dissolução da imagem ocidental do homem (cujos inícios remontam à Renascença). ${ }^{9}$ Ele deseja situar o ser humano não no plano das essências mas no do devir e da multiplicidade, e concomitantemente busca fazer com que o ser humano entre em contato com sua fereza e seus "maus sentimentos".

Talvez não haja nada mais surpreendente para quem considera o mundo grego do que descobrir que os gregos davam a todas as suas paixões e maus pendores naturais, de tempo em tempo, como que festas e até mesmo instituíram estatalmente uma espécie de ordenamento de celebrações de seu demasiado-humano: é isto o propriamente pagão de seu mundo, que, a partir do cristianismo, não é nunca compreendido, não pode nunca ser compreendido e é sempre combatido e desprezado do modo mais duro. (Humano Demasiado Humano, 220)

O dualismo, sempre presente na metafísica e na moral cristã, nos torna habitantes de um duplo mundo (deste e do mundo futuro) onde acima de tudo é preciso represar e internalizar os sentimentos tidos como imorais e maus:

Não é pavoroso fazer de sentimentos necessários e regulares uma fonte de miséria interior e, dessa forma, querer fazer da miséria interior, em todo homem, algo necessário e regular? Além disso, é ainda uma miséria mantida em segredo e, com isso, mais profundamente arraigada: pois nem todos têm a coragem de Shakespeare, de confessar suas trevas cristãs nesse ponto, assim como ele o fez em seus sonetos. Então algo, contra o que se tem de combater, que se tem de manter dentro de limites ou, em certas circunstâncias, afastar inteiramente dos sentidos, deve ser sempre chamado de mau? Não é próprio de almas vulgares sempre pensar mal de um inimigo? (Aurora, 76)

8 V. Marton, S., Extravagâncias, Discurso editorial, São Paulo, 2000, p.138.

9 Cf. Vaz, H.C.L, Antropologia Filosófica I, São Paulo, Loyola, 1991, p.133. 
Nietzsche defende a maneira grega (pré-socrática) de se relacionar com aquilo que posteriormente é considerado "impureza" no ser humano:

Eles [os gregos] tomavam esse demasiado-humano como inevitável e preferiam, em vez de insultá-lo, dar-lhe uma espécie de direito de segunda classe, ordenando-o dentro dos usos da sociedade e do culto: aliás, tudo o que tem potência no homem eles denominavam divino, e o inscreviam nas paredes de seu céu. Não negam o impulso natural que se exprime nas propriedades ruins, mas o ordenam e o limitam a cultos e dias determinados, depois de terem inventado suficientes medidas preventivas para poderem dar àquelas águas selvagens a vazão mais inócua possível. (Humano Demasiado Humano, 220)

E o que acontece com o agir dentro da perspectiva nietzscheana do ser humano?

A vontade de potência mascararia um certo tipo de "naturalismo" e "espontaneísmo", onde o ser humano está somente entregue aos seus instintos, onde a praxis humana prescinde de fundamentação? A reflexão nietzscheana sobre o além-do-homem nos traz mais dados para essa discussão: o ser humano não pode ser visto como um fim, mas como um meio para a conquista de possibilidades mais sublimes de vida. "O homem é algo que deve ser superado, é uma corda estendida entre o animal e o além-do-homem..." (Assim Falou Zaratustra, Prefácio 2.3) (10 $^{10}$

Ambicionar a realização do além-do-homem é uma tarefa que só pode ser realizada por intermédio da vontade de potência. E esta, para Nietzsche - como já mencionado - é uma vontade dessubstancializada e múltipla. Se é a vontade que determina o surgimento e a transformação de todo estado de coisas do universo, tal vontade difere de uma vontade psicológica e unívoca, que é antes de mais nada uma superstição.

A crítica à razão, à vontade (à alma, à causalidade, às tradicionais categorias do pensamento de até então) - e cabe ressaltar aqui, também à moral - implica uma reflexão sobre o agir humano. A crítica à moral é uma genealogia fundada na vontade de potência - uma vontade de potência ativa, afirmativa, capaz de desmascarar as idéias e valores modernos como simples manifestações de uma vontade de potência reativa, negadora e niliista.

A praxis não deve ser uma praxis cega, ou um retorno à animalidade embrutecedora, mas deve ser pautada pelo emprego da vontade de potência ativa.

10 "Der Mensch ist Etwas, das überwunden werden soll. Der Mensch ist ein Seil, geknüpft zwischen Thier und Übermensch."( Also sprach Zarathustra, Vorrede 2.3, Colli und Montinari, pp.14, 16) 
O dever ser e o agir humano em Nietzsche não pretendem nos remeter a um "sistema moral", pois buscam uma superação dele. Mas ele alcança essa superação? Nietzsche não busca estabelecer um programa, um plano normativo, um "sistema moral", no entanto fala sobre o que deve ser o agir humano. Apesar de não apresentar nenhum plano moral, fala sobre um tipo de ser humano desejável, o "além-do-homem", e isto por si só já significa, quer queira ou não, uma reflexão ética.

Ao não poder se liberar da exigência filosófica de conceber o que é e o que deve ser (é o que nos mostra a Genealogia da Moral e a Umwertung), e ao ter que sustentar ao mesmo tempo que essa exigência é filosoficamente irrealizável - pois baseia-se no perspectivismo e na crítica da verdade absoluta - Nietzsche coloca para si mais outra aporia.

O agir depende tão somente de "valores", mas que valores são esses e para onde nos conduzem? Nietzsche não pode definir os valores de modo unívoco e nem especificar o caminho que devemos tomar, pois isto seria normatizar: projeto irrealizável e negador de sua filosofia.

Sua única arma, e a de cada um, seria então unicamente a crítica, o discurso apofático, a negatividade? A filosofia nietzscheana é somente uma filosofia do para-si ou a filosofia do para-si de cada um, que traz em seu bojo a promessa da autodestruição e autosuperação? A ambicionada transvaloração da cultura se restringiria às ações particulares?

Mediante a reflexão sobre a gênese do que considera niilismo, e sobre o conceito de vontade de potência, Nietzsche tenta resgatar elementos que possibilitem uma visão orientadora do agir. Visão esta que, em última instância, atribui a cada um a autonomia para criar um mundo para si (um mundo de valores inventados pelo próprio ser humano). Esse mundo-para-si é o reconhecimento e valorização de certa incomunicabilidade (Zaratustra se orgulha de sua solidão, que ele próprio ressalta não ser sinônimo de mutismo). É a eleição da alteridade, de uma alteridade que não deve ser entendida como negatividade ou obstrução de vida, mas ao contrário, como a plenificação do que vale a pena ser vivido, isto é, o oposto da uniformização e massificação de valores.

Assim, o social para Nietzsche implica diferença, classes, hierarquia. Os ideais humanitários de igualdade, presentes já no cristianismo ("Todos os homens são iguais perante Deus"), que se tornaram bordão na Revolução Francesa e nas democracias, deságuam na mediocridade do nivelamento dos valores mais insignificantes para a vida.

O niilismo, surgido já na Grécia e expandido aos séculos futuros, é o recrudescimento de valores e ideais negadores da vida. A necessida- 
de de novos valores e de uma cultura diferenciada passa, em Nietzsche, por uma reflexão crítica que tematiza filosoficamente o agir.

A fundamentação filosófica da transmutação de todos os valores liga-se, em última instância, à teoria da vontade de potência e à hipótese do eterno retorno. Isto é, remetem-nos à sua cosmologia.

Mas é possível "definir" esses conceitos de maneira universal? Deparamos sempre com a volatilidade do pensamento nietzscheano, e de novo com a questão da verdade como intensificação da vontade de potência.

É descabida a pretensão de compreender a essência do mundo (e dos conceitos) e a partir daí orientar o ser humano em sua ação. O que é vivido pelo ser humano tem que ser interpretado e valorado.

Onde encontrei um ser vivente, lá encontrei vontade de potência... E esse mistério segredou-me a própria vida: 'Veja', disse ela, 'eu sou aquela que sempre tem de superar a si mesma'. (Assim falou Zaratustra, Also sprach Zarathustra, II, "Da superação de si") ${ }^{11}$

Essa superação é realizada através das "tábuas de valor": "Uma tábua de valores está suspensa sobre cada povo. Olha, é a tábua de suas superações; olha, é a voz de sua vontade de potência" (Assim Falou Zaratustra, I, "Dos mil e um alvos"). ${ }^{12}$

A teoria da vontade de potência está ligada à doutrina perspectivista que rompe com a teoria tradicional do conhecimento. Não havendo conhecimentos e fatos em si, não havendo aparência, resta o valorar segundo a vontade de potência: é ela que norteia a Umwertung.

Devemos agora rever algumas questões pendentes: a Umwertung almejada por Nietzsche seria apenas uma utopia?

A filosofia nietzscheana da maturidade é uma busca da subversão dos valores do ascetismo cristão (considerados como inspiradores dos ideais civilizatórios do Ocidente); no entanto, a transvaloração desejada por ele não poderia ser tida apenas como a antítese dos valores cristãos. De outro modo se cairía novamente no dualismo tão criticado por ele próprio.

11 "Wo ich Lebendiges fand, da fand ich Willen zur Macht (...). Und diess Geheimniss redete das Leben selber zu mir. "Siehe, sprach es, ich bin das, was sich immer selber über-winden muss". (Von der Selbst-Ueberwindung, Colli und Montinari, pp.147-148).

12 "Eine Tafel der Güter hängt über jedem Volke. Siehe, es ist seiner Überwindung Tafel; siehe, es ist die Stimme seines Willens zut Macht." (Also sprach Zarathustra, Von tausend und Einem Ziele", Colli und Montinari, p. 74). 
É durante o segundo semestre de 1888 que Nietzsche elabora o plano para sua obra Transvaloração de todos os valores: 1) Primeiro livro O Anticristo. Ensaio de uma crítica do cristianismo. 2) Segundo Livro O Espírito Livre. Crítica da filosofia como movimento niilista. 3) Terceiro Livro - O Imoralista. Crítica da mais fatal espécie de ignorância, a moral. 4) Quarto Livro - Dionísio. Filosofia do eterno retorno (Fragmentos póstumos - XIII 19 [8] de setembro de 1888).

Desse plano Nietzsche só chega a escrever o primeiro título: O Anticristo. Apesar da tetralogia não ter sido finalizada em termos de sua escrita, Nietzsche identificaria O Anticristo com o conteúdo geral da Transvaloração. ${ }^{13}$

Mas (independentemente de $O$ Anticristo possuir ou não conteúdo total da Transvaloração plenamente desenvolvido) uma relevante questão se impõe: além da crítica e negatividade, haveria aspectos afirmativos no projeto transvalorador de Nietzsche? Haveria, de fato, alguma vertente construtiva no pensamento nietzscheano? Os possíveis aspectos afirmativos da Unwertung (que inicialmente estariam presentes no suposto quarto livro da obra - Dionísio) não se apresentam claramente, ou, se existem, passam pela forma da negatividade.

A idéia de que o pensamento nietzscheano enclausura-se, encerra-se em negações, críticas e aporias, e não teria conseguido, por isso, apresentar algo que não fosse unicamente destrutivo, é a opinião de diversos autores. ${ }^{14}$

Ao largo dessas considerações encontra-se a hipótese de que a Umwertung já estaria pressuposta, e de certa forma realizada em $O$ Anticristo, também de forma afirmativa. ${ }^{15}$ Em $O$ Anticristo teríamos um uso positivo de conceitos originariamente negativos, o que estimularia o surgimento de uma nova tábua valorativa, um tipo cultural de homem diverso, tal como Nietzsche almejava. Nietzsche teria conquistado, além do mais, sob o ponto de vista pessoal, uma posição transvalorada. Sua busca de uma nova escala de valores (que passa pela reabilitação dos instintos fundamentais, pela não-negação do mundo nem da natureza; pela redescoberta do âmbito polimorfo do vir-a-ser) teria partido, antes de mais nada, de si mesmo.

13 Ele escreve numa carta a Paul Deussen, em 26 de novembro de 1888, que "Minha Transvaloração de todos os valores, cujo título principal é O Anticristo, está terminada".

14 V. Barros, F. M., A maldição transvalorada. São Paulo: Discurso Editorial, 2002, p. 22: Eugen Fink e Arthur Danto sustentariam essa posição.

15 Idem, p. 23. 
Ao negar a negação da existência terrena, ao descrever a moral cristã como o desprezo perante o existir, concebe um filosofar anticristão: ${ }^{16}$ o não afirmar como uma espécie de afirmação.

Como já dito, a esse ponto de vista associa-se a hipótese de que Nietzsche teria experienciado o que escrevia, isto é, ele teria sido o primeiro e principal agente da transvaloração. A verdade é que o próprio Nietzsche se julgava inaugurador de uma nova era ${ }^{17}$ e se considerava agenciador de experimentos valorativos: "Que cada um invente para si a sua virtude, o seu imperativo categórico" $(A C, 11)$.

Mas mesmo supondo que ele tenha experienciado e vivido os pressupostos de sua Umwertung (apesar de ao fim do próprio projeto crítico ter se colocado como "homem-bomba"), ${ }^{18}$ o que obteve em favor da realização transpessoal de seu projeto? O fato de ter estabelecido que a cada um cabe a autonomia para criar um modo próprio de agir (a apologia da diferença e da alteridade)?

Voltando à pergunta que desencadeou essas reflexões: a Umwertung seria um devaneio? A resposta de que Nietzsche teria sido o principal agente da transvaloração, e que teria agregado uma dimensão corpórea ao seu empreendimento de transvaloração (e por isso seu projeto não teria sido acidentalmente interrompido pela crise que teve) é insatisfatória? Esse é o ponto máximo para o qual podemos distender a realização da transvaloração, e se isso condiz ou não com os objetivos que Nietzsche pretendia alcançar é outra questão.

Se em termos de sua efetividade microcultural a Umwertung foi realizada na própria pessoa de Nietzsche (ele teria feito de si próprio a transvaloração de todos os valores), não dá conta da transformação cultural e educacional ambicionada.

No entanto, que tipo de ser humano a Umwertung almejava?

Nietzsche ambicionava modificar a disposição hegemônica dos valores da vida gregária: para ele o zelo pela condição pessoal era, até então, inferior em relação ao sentimento de afeição ao grupo.

16 Idem, p. 125: "Retirando a negatividade do modo reativo da negação, de sua esfera ressentida e reacionária, poder-se-ia, inclusive, cogitar que a corrosibilidade que atravessa e conclui as páginas de Anticristo constitui, no fundo, um grande Sim travestido de Não. Reação ativa, e não-reativa, dizer-se-ia. Condenando sem existir sob modo de ser condenatório, o autor de $O$ Anticristo tomaria distância dos demais iconoclastas"...

17 "Transvaloração de todos os valores: eis a minha fórmula para um ato de suprema consciência da humanidade, que em mim se fez gênio e carne" (EH, Por que sou um destino, 1).

18 Barros, op. cit., p.183: "A auto-implosão do filósofo não deve ser vista como mortificação. Empregando toda sua vitalidade contra o antinaturalismo cristão, ele detona a si mesmo em favor do vira-ser e, como este, entende a sua destruição como criação e não como auto-aniquilamento. Destrói porque sabe que esse é justamente o pressuposto para seguir, continuamente, criando..." 
Contudo, o além-do-homem nietzscheano não se fundaria nem na noção de indivíduo (sujeito, cidadão) nem na de massa, noções tão corriqueiras hoje. Ao falarmos sobre o além-do-homem cabe ressaltar que esse conceito refere-se a um tipo de ser humano, e não a um tipo ou ideal de "humanidade": "Nicht Menschheit, sondern Übermensch, ist das Ziel" (W.M., n.1001). Nietzsche não esperava a "evolução da humanidade", nem a chegada de uma classe universal (como a preconizada por Marx).

Ele não desejava estabelecer uma nova finalidade para a existência (o homem não precisa acreditar que sabe por que existe, existe porque existe). A idéia de finalidade encobriria, na verdade, o desejo de proteção dos interesses da "espécie": como se houvesse um "destino" ou "vocação" da humanidade que devesse se cumprir sob a forma de gregarização, de uma inserção perfeita do indivíduo na espécie (como se isso prevenisse crises e tensões). Desse modo rejeita a noção de espécie humana: nunca teria havido esse ser coletivo (a humanidade), ainda mais investido de uma missão, e conseqüentemente rejeita também a idéia do pertencimento do indivíduo humano à espécie. Quando a vida individual é compreendida como um modo de vida genérico, os indivíduos são considerados seres genéricos determinados, onde se almeja principalmente uma diminuição das diferenças que os separam.

Em suma, o além do homem não representa o "fim último" de nosso processo histórico, ele não deve ser considerado como o resultado de um esforço coletivo; isso nos remeteria novamente ao modelo dos antigos "ideais", e ao desejo de impor à história um sentido. Não se trata também de querer mobilizar o povo (como no socialismo), como se a conquista do além-do-homem fosse um alvo a ser atingido. ${ }^{19}$

Imaginar o além-do-homem como meta a ser atingida seria continuar a desejar o futuro, na Terra, à maneira como os cristãos desejam o reino de Deus nos céus. Essa crença é o resultado de séculos fundados no ideal cristão, é o desejo de se aproximar de um tipo único, é achar que todo afastamento em relação a essa unidade é regressão, perda de força para o ser humano (W.M., 339). O além-do-homem implica uma crítica aos ideais cristãos, e não procura estabelecer e explicitar para os seres humanos o futuro do qual são portadores $(A C, 4)$ :

Puisse la saine raison nous préserver de croire que l'humanité doive jamais découvrir des règles idéales et définitives, et que le bonheur doive toujours

19 Cf. Lebrun, G., "Surhomme et Homme Total". In: Manuscrito II 1. Campinas: 1978, p. 46. 
briller d'un éclat toujours égal, comme le soleil des tropiques, sur les hommes soumis à ces règles... ${ }^{20}$

Ao falar de um "tipo de ser humano", Nietzsche estaria censurando a idéia de universalidade "... pois não visa mais atribuir ocultamente aos homens o universal que lhes teria sido ocultado..." ${ }^{21}$ Eis um dos cernes de sua crítica ao projeto civilizatório do Ocidente promovido pelo cristianismo.

Mas voltando ao além-do-homem, ele: “....n'est sûrement pas le terme d'une longue marche de l'humanité. Il nomme plutôt le vide dans lequel nous serons assurés de ne plus nous laisser piéger par des mots comme 'humanité'". ${ }^{22} \mathrm{O}$ além-do-homem designa antes de tudo o recuo a ser tomado em relação à tradição na qual estamos mergulhados. Não é um "ideal" edificante, mas o discernimento dessa tradição (baseada na domesticação dos indivíduos; domesticação universalista). É o convite a um deslocamento que nos leva a desconfiar sistematicamente de nossas avaliações presentes, não representa um "tipo ideal" de humanidade". O além-do-homem deve ser a ruptura com a submissão ao universal (e ao individualismo, para não se cair no extremo oposto desse dualismo), visa a um domínio de si que não passe pela sujeição ao universal.

Seria anti-nietzscheano apresentar uma caracterização definitiva da Umwertung, ou do além-do-homem: pois Nietzsche deseja justamente fugir dos preceitos que afirmam essências normativas para o humano. ${ }^{23}$

Com isso Nietzsche recai em um discurso apofático: retornamos ao indeterminismo de seu pensamento (marca de seu discurso "apofático").

Encerremos a discussão sobre o além-do-homem concluindo: Nietzsche possivelmente sofre a influência de seu tempo ao referendar a idéia de que a "salvação" surge a partir da miséria em seu extremo estado. ${ }^{24}$ Se os "espíritos livres" devem ser os últimos a querer interromper a decadência de nossa civilização é porque consideram que somente transpondo-a é que virá um nova forma de valorar a existência; em

20 Idem, (Intempestives).

21 Idem., p.48.

22 Idem, p. 52

23 Ver Barros, op. cit., pp. 138, 139: "De fato os detalhes especificamente instrumentais e materiais do processo de elevação do valorar humano praticamente não são explicitados pelo pensador, que se restringe, na maior parte das vezes, a afirmar a possibilidade de sua existência. Nós podemos produzir tais condições nas quais semelhante elevação é possível" (Fragmentos póstumos - XII 9 [153] do outono de 1887).

24 Cf. Lebrun, G., op. cit., p. 56. 
outras palavras, se do ponto de vista político o advento do socialismo deve ser desejado é porque acelerará a "decadência" ${ }^{25}$

Somente tendo passado por ele é que nos convenceremos de que nossa "civilização" não oferece mais recurso político contra a decadência. A possibilidade de mudança, mesmo social, passa em Nietzsche não pela política, mas pela educação e transformação cultural. ${ }^{26}$

CUNHA, M. P. S. da. Surrogates for the classical ethics: Nietzsche's reflections on the human actions and his concept of overman. Trans/Form/Ação, (São Paulo), v.28(1), 2005, p.49-65.

- ABSTRACT: Based on Nietzsche's reflections about the human action and the overman, this article focuses on that philosopher's devastating criticism of the classical ethics in the light of the $19^{\text {th }}$ century broader deconstruction context of the ingrained former ethical values. Two issues are highlighted: Did the suspicions he threw on classical ethics unleash an ethical void? Would the historical and social realization of the Unwertung be just an utopia?

- KEYWORDS: Nietzsche; ethics; deconstruction, reason; dualism.

\section{Referências bibliográficas}

Obras de Nietzsche e sobre Nietzsche:

NIETZSCHE, F. Kritische Gesamtausgabe Werke. Berlim: De Gruyter (G.Colli e C. Montinari); Paris: Gallimard.

. Obras Incompletas. São Paulo: Ed. Abril Cultural, col. Os Pensadores, 1978.

ANDLER, C. Nietzsche, sa vie et sa pensée. Paris: Gallimard, 1958.

AZEREDO, V. D. de. Nietzsche e a dissolução da moral. São Paulo: Discurso Editorial/Editora Unijuí, 2000.

25 A crítica nietzscheana ao marxismo e socialismo funda-se na idéia de que essas tendências dão seguimento à tradição universalista, isto é, nem sequer chegam a contestar as bases civilizatórias do Ocidente. Elas na verdade reafirmariam os mitos do tempo: a idéia de progresso, de crescimento econômico racional, preservando, subrepticiamente, os ideais da sociedade prometida, gerando Estados totalitários (Lebrun, op. cit. p. 58).

26 Idem, p. 57. 
BARROS, F. M. A maldição transvalorada. São Paulo: Discurso Editorial, 2002.

BATAILLE, G. Sur Nietzsche. Paris: Gallimard, 1945.

BOYER, A. et alii. Pourquoi nous ne sommes pas nietzschéens. Paris: Bernard Grasser/Fasquelle, 1991; em português, Por que não somos nietzscheanos. São Paulo: Editora Ensaio, 1994.

DANTO, A. Nietzsche as philosopher. Nova York: Columbia University Press, 1965.

DELEUZE, G. Nietzsche et la philosophie. Paris: Presses Universitaires de France, 1973.

FOUCAULT, M. "Nietzsche, Freud, Marx". In: Nietzsche, Cahiers de Royaumont. Paris: Minuit, 1967.

GRANIER, J. Le problème de la vérité dans la philosophie de Nietzsche. Paris: Seuil, 1966.

GRIMM, R. Nietzsche's theory of knowledge. Berlim: Walter de Gruyter Co., 1977.

HEIDEGGER, M. Nietzsche. Paris: Gallimard, 1971.

HABERMAS, J. Connaissance et intérêt. Paris: Gallimard, 1976.

La crítica nihilista del conocimiento en Nietzsche. Revista Teorema, Valencia, 1977.

Sobre Nietzsche y otros ensayos. Mexico: Rei, 1996.

JASPERS, K. Nietzsche. Introduction à sa Philosophie. Paris: Gallimard.

KAUFMANN, W. Nietzsche, philosopher, psychologist, antichrist. Nova York: The World Publishing Co., 10 ed., 1965.

LEBRUN, M. "Surhomme et Homme Total." Manuscrito, vol. II, núm.1. Campinas: CLE/Unicamp, 1978, p. 31-58.

MARTON, S. Nietzsche: das Forças Cósmicas aos Valores Humanos. São Paulo: Brasiliense, 1990.

MARTON, S. (org.) Nietzsche hoje?; colóquio de Cerisy. São Paulo: Brasiliense, 1985.

Nietzsche; uma filosofia a marteladas. São Paulo: Brasiliense, 5 ed., 1991.

Nietzsche, cosmologia e genealogia. São Paulo, Tese de doutoramento, USP, 1988, p. 374.

MÜLLER-LAUTER. A Doutrina da Vontade de Poder em Nietzsche. Trad. Oswaldo Giacóia Junior. São Paulo: AnnaBlume, 1997. 